\title{
A Study on the Influence of Promotion of Garuda Indonesia by Social Media on e-WOM, Online Ticket Sales, Brand Image, and Brand Loyalty During the Covid-19 Pandemic
}

\author{
Johar Samosir ${ }^{\mathrm{a}}$, Hendro Kuntohadi ${ }^{\mathrm{b}}$, Sarinah Sihombing ${ }^{\mathrm{c}}$, Laura Mia Fadillah ${ }^{\mathrm{d}}$, Dina Afifah ${ }^{\mathrm{e}}$ \\ a,b,c,d,e,fITL Trisakti \\ joharsamosir@yahoo.co.id, bhkuntohadi2011@gmail.com, ${ }^{\text {c }}$ sarinah.stmt@gmail.com, ${ }^{\mathrm{d}}$ lauramiaf@gmail.com, ${ }^{\mathrm{e}}$ \\ inaafifah1699@gmail.com
}

Article History: Received: 10 November 2020; Revised 12 January 2021 Accepted: 27 January 2021; Published online: 5 April 2021

\begin{abstract}
This study investigates the impact brand identity of three of the promotional information characteristics of airline social media information quantity, credibility of information, and quality of information through electronic word-of - mouth (eWOM). We did a survey 250 customers who had been using social media from Garuda Indonesia airlines to interpret and evaluate data obtained using structural equations. The findings of this study showed that the promotion of social media airlines had a positive impact on e-WOM, e-WOM had such a positive effect on the brand's image and e-WOM even had a noticeable impact on the selling of online tickets. This study sets out a model for social media information characteristics and can be used as basic data to illustrate how airlines can handle and use social media information.
\end{abstract}

Keywords: Brand image, e-WOM, Promotion, Online Ticket Sales, Garuda Indonesia

\section{Introduction}

Rapid technological advances have occurred at the global level, this actually encourages technology users to quickly adapt. Even when the COVID-19 pandemic, technological growth grew, this was due to adjusting community activities. Social media is becoming a technology for interacting between individuals widely. Even social media has become one of the tools for exchanging information and marketing a product by other companies or institutions. Because of the existence of social media e-WOM will be created which is used as a marketing tool by many groups. e-WOM is now one of the important strategies, because with e-WOM customers will trust the brand image of a product or service being marketed. In airlines now online ticket sales are influenced by social media promotion and corporate brand image. Now, over time, the flight ticket sales system has changed, which was originally offline and is now online.

COVID - 19 is a virus that has a very fast spreading pattern, so the solution to suppress the spread of the virus, the community must make various efforts, one of which is physical distance. The government has also tried to reduce the spread of COVID-19 figures, one of which is by implementing Large Scale Social Restrictions (PSBB). This fact results in the community having limitations to carry out activities in public places, so that many sectors of trade and services, especially air transportation services like Garuda Indonesia Airlines.

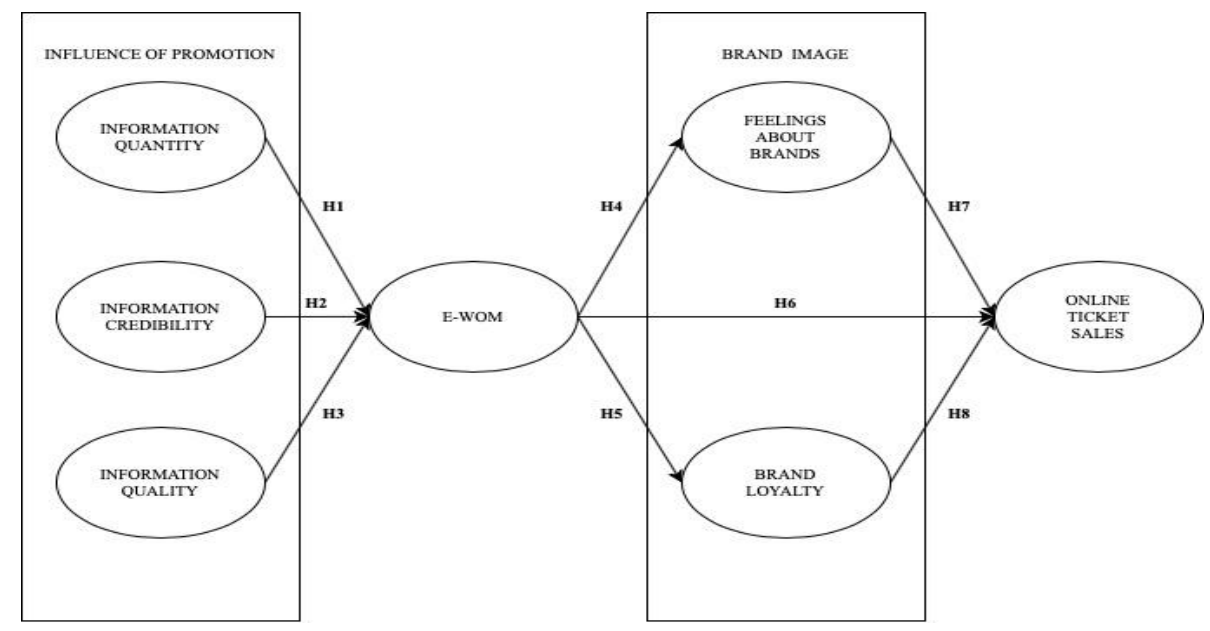

Figure 1. Research Model 


\section{Social Media}

Social media is a content produced by users and compared to traditional marketing communication methods it is considered effective in shaping the perceptions and behaviors of other users (Parveen et al., 2015)[1]. Social media helps consumers more active in searching, comparing, choosing and purchasing products and service, so that customers feel more informed (Constantinides, 2014)[2]. Social media also provides ways to communicate with consumers so that they can interact more broadly(C.M., 2012)[3].

\section{Influence Of Promotions}

Basically, information quantity has a relationship in making a buying decision. Much or less information that is obtained related to the product will always be needed in decision making, consumers tend to consider more brands than they want. Excessive quantity of information allows consumers to experience a worse subjective decline in their decisions. Thus, the quantity of information includes the amount of information obtained per choice or number of choices (Seo \& Park, 2018) [4].

Information credibility must provide a trust so that it can affect the convenience and information of the product at the time of the purchase transaction and also on solving customer problems. Credibility of information becomes a process of information exchange and knowledge integration, this is because consumers need useful information so they can better assess and evaluate information. ("Building Community Social Capital: The Potential and Promise of Information and Communications Technologies," 2004) [5].

Information quality is a way to test a product or service so that it can provide useful information to customers (Chen \& Tseng, 2011) [6]. Information quality has a relationship with E-WOM, because it is a factor that has a positive influence on E-WOM, this has been proven in previous studies (Kim \& Kim, 2010) [7].

H1. Promoting the quantity of information on social media will have a positive impact on e-WOM.

H2. Promoting social media information reputation would have a significant positive impact on e-WOM.

H3. Promoting information quality on social media would have a significant positive impact on e-WOM.

\section{e-WOM}

E-wom have been around for a long timeused as a powerful marketing tool. The characteristics of information from the internet influence consumer behavior more than internet information produced by marketers(Bickart \& Schindler, 2001)[8]. E-WOM can be interpreted as a positive or negative opinion that is valued by customers based on potential, actual, or opinions about previous customers about a product or company, to be a reference for many people and institutions through the internet.(López \& Sicilia, 2014)[9]. Trust in something is born out of a social relationship. Because of the increased credibility of information arising from a sense of trust in something, it can be used as a facility for information exchange and information use (Chu \& Choi, 2011)[10].

H4.E-WOM should have a huge positive influence on brand feelings.

H5. E-WOM should have a significant positive on brand loyalty

H6. E-WOM have a significant positive on online ticket sales

\section{Brand Image}

Thought and consumer feelings about the brand can be defined as brand image. (Sallam, 2016)[11]. Brand image has an impact on consumer perception in the company which is considered as one of the most important intangible assets.(Agmeka et al., 2019)[12]. In the marketing environment the feelings that emerge from the brand have received more attention.(Kapoor, 2016)[13].

\section{Brand Loyalty}

Brand loyalty was described by Ali and Muqadas (2015) as a notion of re-buying intent and psychological commitment. In the same pattern, brand loyalty was described by Dehdashti et al. ( 2012) as a long-term relationship based on the re-purchase intent of a customer and continuing commitment to a brand (MOHAMMAD, 2017) [14]. Furthermore, Dick and Basu (1994) suggest other marketing benefits associated with loyalty, Such as a greater resistance among loyal customers to competitive strategies and a strong word of mouth[15]. For at least four decades, the concept of brand loyalty has been recognized as an important construct in marketing literature (Howard and Sheth, 1969) [16]. 


\section{Online Ticket Sales}

Now most airlines have begun implementing electronic tickets as a means to receive consumers, this is a sign that airlines are adapting to online media(Crespo-Almendros \& Del Barrio-García, 2016)[17].Electronic marketing is a strategy, system, and marketing process that uses information and communication technology supported by the internet.(Purwitasari et al., 2019)[18]. In 2007 growth in ticketing pushed the International Air Transport Association(IATA) to turn a paper ticket into an electronic ticket. (Sulaiman et al., 2008)[19].

H7. Feels about brand will have a significant positive effect on online ticket sales

H8. Brand loyalty have a significant positive on online ticket sales

\section{Method}

The analysis was carried out using quantitative methods. We verified 250 customers who had been using social media from Garuda Indonesia airlinesto interpret and evaluate data obtained using structural equations. Materials used to calculate research variables have been adapted from (Seo \& Park, 2018) and some changes to fit the context of the study. The 5-point Likert scale is used, where 5 points indicate "very agree" and 1 point indicates "very disagree". Techniques used in the analysis and interpretation of data. The analytical data used is SEM (Structural Equation Modeling) in accordance with the model developed in this study, which is supported through AMOS 24 program (Hair et al., 2006) [17].

\section{Discussion \& Result}

The question used here research was designed first by doing a conceptual review related literature and afterwards incorporating and updating the elements of the questionnaire. The question divides the aspects of the information on airline social media promotion into information credibility (4), information quality (3), and informationquantities (3), thus forming ten questions. In addition, surveys as specific questions more about customers characteristic and social media characteristics their use, as well as specific questions about factors such as brand loyalty, feelings about brands, online ticket sales, and e-WOM. The survey was conducted from $27^{\text {th }}$ June 2020 to $29^{\text {th }}$ June 2020 for people who used social media as an information tool for promoting Garuda Indonesia airlines.

Table 1.Survey Item

\begin{tabular}{ll}
\hline Variable & Measurement Items \\
\hline \multirow{2}{*}{$\begin{array}{l}\text { Informatio } \\
\text { n Quantity }\end{array}$} & $\begin{array}{l}\text { Garuda Indonesia airline social media has a lot of information about the } \\
\text { promotions given. } \\
\text { Many people post promotional information about Garuda Indonesia airlines on } \\
\text { social media. }\end{array}$ \\
\hline & $\begin{array}{l}\text { In my opinion the information on social media provided by the Garuda Indonesia } \\
\text { airline regarding regulations during the Covid - 19 pandemic can be trusted. }\end{array}$ \\
Informatio & $\begin{array}{l}\text { In my opinion, information on social media about the health protocol provided by } \\
\text { the Garuda Indonesia airline when the Covid - 19 pandemic is clear. }\end{array}$ \\
Credibility & $\begin{array}{l}\text { In my opinion the information on social media provided by the Garuda Indonesia } \\
\text { airline during the Covid - 19 pandemic was very influential. }\end{array}$ \\
& $\begin{array}{l}\text { In my opinion Information on social media related to flight unavailability due to } \\
\text { large-scale social restrictions is clear. }\end{array}$ \\
\hline Informatio & $\begin{array}{l}\text { I can easily understand the information provided on the Garuda Indonesia social } \\
\text { media. }\end{array}$ \\
I feel that the Garuda Indonesia airline's social media information can be trusted. \\
Overall, I believe the quality of information provided on social media on Garuda \\
Indonesia airline is great.
\end{tabular}




\begin{tabular}{ll}
\hline Loyalty & Compared to other airlines, I feel satisfied using this airline. \\
& I'll be willing to repeat the purchase. \\
\hline Online & $\begin{array}{l}\text { Garuda Indonesia online ticket sales service makes it easy for me. } \\
\text { Ticket }\end{array}$ \\
Online ticket sale helps in purchasing Garuda Indonesia tickets. \\
$\begin{array}{l}\text { I feel confident using Garuda Indonesia ticket sales online because of promotions } \\
\text { given by the company. }\end{array}$
\end{tabular}

Source: (Seo \& Park, 2018) [4]

Analyze respondent characteristics by examining population frequency and general characteristics. The respondents consisted of $115(46 \%)$ men and $135(54 \%)$ women. $116(46.4 \%)$ respondents aged between 17 and 25, $56(22.4 \%)$ aged between 26 and 35, 24 (9.6\%) aged between 36 and 45, $29(11.6 \%)$ respondents aged 45 and $55,25(10 \%)$ respondents age $>56.152(60.8 \%)$ of respondents traveled for tourism / vacation purposes, 32 $(12.8 \%)$ traveled on business or met other commercial destinations, 27 (10.8\%) traveled for official trip, 39 $(12.8 \%)$ traveling for Educational purposes. The following is the purpose of travel using the airline, which is tourism/vacation spot $152(60.8 \%) .103(41.2 \%)$ of the student respondents, $64(25.6 \%)$ of the employee respondents, $29(11.6 \%)$ of the entrepreneurial respondents, $25(10 \%)$ of the teacher/lecturer respondents, and 29 $(11,6 \%)$ of other respondents.

Table 2.Demographic Characteristics of Respondents.

\begin{tabular}{llll}
\hline Category & & Frequency (person) & Ratio (\%) \\
\hline \multirow{2}{*}{ Gender } & Male & 115 & 46 \\
& Female & 135 & 54 \\
\hline \multirow{4}{*}{ Age } & $17-25$ & 116 & 46,4 \\
& $26-35$ & 56 & 22,4 \\
& $36-45$ & 24 & 9,6 \\
& $46-56$ & 29 & 11,6 \\
& $>56$ & 25 & 10 \\
\hline \multirow{4}{*}{ Purpose of trip } & Tourism trip & 152 & 60,8 \\
& Study trip & 39 & 15,6 \\
& Bussines trip & 32 & 12,8 \\
& Official trip & 27 & 10,8 \\
\hline \multirow{4}{*}{ Proffesion } & College student/student & 103 & 41,2 \\
& Employee & 64 & 25,6 \\
& Entrepreneur & 29 & 11,6 \\
& Teacher/lecture & 25 & 10 \\
\hline Total Number of Respondents & 29 & 11,6 \\
\hline Own Calculation & Others & 250 & $100 \%$ \\
\hline
\end{tabular}

\section{Source : Own Calculation, 2020}

Within this study we checked the validity by conducting a confirmatory factor analysis for a measuring model before evaluating the research hypotheses.Convergent validity was obtained by showing that for all measured items the Squared Multiple Correlations (SMCs) values were 0.5 or more, while the Standardized Regression Weight (SRWs) values were 0.7 or greater.

Table 3. Results of confirmatory factor analysis for constructs.

\begin{tabular}{|c|c|c|c|c|c|}
\hline $\begin{array}{l}\text { Constru } \\
\text { ct }\end{array}$ & $\begin{array}{l}\text { Variable } \\
\text { Measured }\end{array}$ & SMC & $\begin{array}{l}\text { Regression } \\
\text { Coefficient } \\
\text { (C.R.) }\end{array}$ & $\begin{array}{l}\text { Standardized } \\
\text { C.R. }\end{array}$ & $\alpha$ \\
\hline \multirow{10}{*}{$\begin{array}{l}\text { Influenc } \\
\text { e of } \\
\text { Promoti } \\
\text { on }\end{array}$} & Information & 0.47 & 1.00 (Fixed) & 0.69 & \multirow{6}{*}{0.82} \\
\hline & Quantity 1 & & & & \\
\hline & Information & 0.71 & $1.01(8.32)$ & 0.84 & \\
\hline & Quantity 2 & & & & \\
\hline & Information & 0.41 & $1.05(8.37)$ & 0.64 & \\
\hline & Quantity 3 & & & & \\
\hline & $\begin{array}{l}\text { InformationCredibil } \\
\text { ity } 1\end{array}$ & 0.50 & 1.00 (Fixed) & 0.71 & \multirow{4}{*}{0.86} \\
\hline & Information & 0.63 & $1.00(9.60)$ & 0.79 & \\
\hline & Credibility 2 & & & & \\
\hline & Information & 0.48 & $0.94(9.03)$ & 0.69 & \\
\hline
\end{tabular}




\begin{tabular}{lllll}
$\begin{array}{l}\text { Credibility 3 } \\
\text { Information } \\
\text { Credibility 4 }\end{array}$ & 0.29 & $0.69(7.26)$ & 0.53 & \\
\hline $\begin{array}{l}\text { Information Quality } \\
1\end{array}$ & 0.75 & 1.00 (Fixed) & 0.87 & \\
$\quad \begin{array}{l}\text { Information Quality } \\
\quad 0.71\end{array}$ & $0.99(14.58)$ & 0.84 & 0.93 \\
$\quad \begin{array}{l}\text { Information Quality } \\
3\end{array}$ & 0.62 & $0.83(13.75)$ & 0.79 & \\
$a$ & & & & \\
\hline
\end{tabular}

Note: $a=$ Cronbach'a

\section{Source: Own Calculation, 2020}

After confirmatory factor study, the analysis of the measurement model was performed to integrate all variables and check the suitability of the model in this research. The fit model in this research is $\chi^{2}=205.40, \mathrm{df}=$ $187, \mathrm{CMIN} / \mathrm{DF}=1.10, p=0.00, \mathrm{GFI}=0.93, \mathrm{RMSEA}=0.02$, AGFI $=0.91$, TLI 0.99, and CFI $=0.99$. In this case, shows that all indexes have met the level of acceptance and overall good suitability. In addition, the AVE value for each construction shows 0.5 or more after measuring for each possible variable in the measurement model. Therefore, in this study there is a convergent validity that exists between the measurement variables used.

To test the hypothesis, analysis of the model structural equation was performed. The research found that the match index is $\chi^{2}=3078.33 \mathrm{df}=231, \mathrm{CMIN} / \mathrm{DF}=13.33, p<0.001, \mathrm{GFI}=0.27, \mathrm{AGFI}=0.20, \mathrm{RMR}=0.21$, RMSEA $=0.22$, TLI 0.00 , and CFI $=0.00$, satisfying match standard of acceptability. The structural model provided in this analysis has therefore been evaluated as suitable. Fig.(2) indicates the analysis results for the hypotheses.

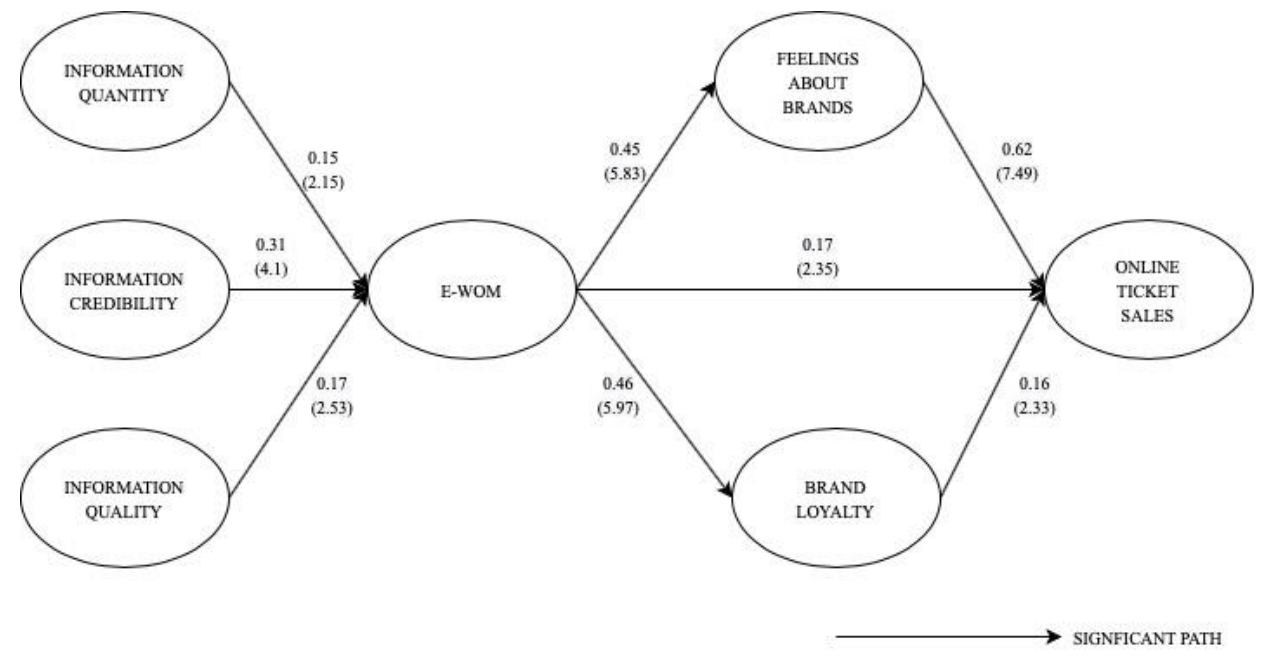

Figure 2. Analysis Results of Research Model

The effect of quantity of information on the e-WOM among the information feature in social media $\beta=0.15$, C.R. $=2.15(\mathrm{p}<0.001)$ Indicating statistically significant effects. This indicates that the amount of social media information is a key variable that can cause e-WOM. Information credibility in social media had a statistically significant effect on e-WOM as $\beta=0.31$, C.R. $=4.1(\mathrm{p}<0.001)$, indicating that the impact is statistically important.The quality of information in social media has had a statistically important impact on e-WOM, as $\beta=$ 0.17 , C.R. $=2.53(\mathrm{p}<0,001)$, clearly shows that e-WOM activity increased as information quality improved. The statistically effect of e-WOM on feelings about brands is $\beta=0.45, C . R .=5.83(p<0,001)$ Showing that e-WOM behavior increased as feelings about brands increased. The statistically important effect of E-WOM on a brand loyalty is $\beta=0.46$, C.R. $=5.97(p<0,001)$, which is the main brand image element. Moreover, the brand image can be improved by e-WOM activities, and this is seen in customer memories when an airline is remembered or identified. In this study, feelings about brands it had a statistically relevant effect on online ticket sales as $\beta=0.62$, C.R. $=7.49(p<0.001)$. E-WOM have a statistically significant impact on on the selling of online tickets is $\beta=$ 0.17, C.R. $=2.53(p<0,001)$. Brand loyalty had statistically significant effect online ticket sales as $\beta=0.16$, C.R. $=2.33(\mathrm{p}<0.001)$. This shows that as the brand image grows, deepening the online ticket sales, and from the company's viewpoint, consumers who create online marketing campaigns become more relevant as they share the values and resources of the company and establish relationships with the business. In other words, e-WOM plays a constructive role in improving the brand identity and creating a high ticket sales rate online. Furthermore, eWOM has a direct effect on online ticket sales information. 


\section{Conclusions}

So the conclusion of this study is that of the 250 respondents dominated for the purpose of holiday travel. Based on the results of the analysis that the characteristics of information promotion have a significant influence on e-WOM, and information credibility has a greater influence among the three characteristics of information promotion.

Therefore, if Garuda Indonesia airline company wants to increase e-WOM, Garuda Indonesia company needs to increase information quantity. Then, the e-WOM variable has a significant influence on feelings about brands, brand loyalty, and online ticket sales, so if the e-WOM strategy implemented by the Garuda Indonesia company is successful and has an increase it will have an impact on the brand image that are felt by customers. Then, brand image also have a direct influence on online ticket sales. So, if feelings about brands and brand loyalty are felt by customers, it will have an impact on online ticket sales. So with that, information credibility has the most important role so that it can give effect to online ticket sales. This is because all variables are mutually sustainable and influential.

A basic results of this research could be summarized as follows; First, the part relating to airline marketing and decision-makers will need to provide their customers with more and more credibility promotional effects and trigger positive e-WOM. Opinion leaders expect social media to create brand profiles in the midst of social media interactions as part of their everyday lives and to actively promote these brands. When the public sees the shared messages, photographs, and videos, they will spread the advertising and express their own views as well. It needs to reconsidered, however, that e-WOM meets clear instructions online. Apart from that, a large number of promotions can be filtered out by many users, filtered for all interesting products, gathered the desired content and analyzed calmly and sophisticatedly.

In this case, the daily lives carried out on a social media can have an effect on the company's brand image and online ticket sales. Many companies and organizations have recognized that brand image is an important component. The strength of a strong brand power has a large effect, is significantly able to provide a risk perception that can be felt by consumers \& influence a customer's decision making. Second, real understanding of a faulty customer's idea. In order to encourage a more nuanced understanding, relationship marketing is important. Such an advertising style attempts to establish an emotional bond like the one that already exists in human relationships and it is known that current consumers already find certain services and goods.Greater relationships can be established through the establishment and strengthening of long-term partnerships with consumers through a organized and personalized brand experience. Certainly the improved bond won't be easily broken.

\section{References}

Parveen, F., Jaafar, N. I., \& Ainin, S. (2015). Social media usage and organizational performance: Reflections of Malaysian social media managers. Telematics and Informatics, 32(1), 67-78. https://doi.org/10.1016/j.tele.2014.03.001

Constantinides, E. (2014). Foundations of Social Media Marketing. Procedia - Social and Behavioral Sciences, 148, 40-57. https://doi.org/10.1016/j.sbspro.2014.07.016

C.M., S. (2012). Customer engagement, buyer-seller relationships, and social media. Management Decision, 50(2), 253-272. https://doi.org/10.1108/00251741211203551

Seo, E.-J., \& Park, J.-W. (2018). A Study on the Influence of the Information Characteristics of Airline Social Media on e-WOM, Brand Equity and Trust. The Open Transportation Journal, 12(1), 289-300. https://doi.org/10.2174/1874447801812010289

Building Community Social Capital: The Potential and Promise of Information and Communications Technologies. (2004). Journal of Community Informatics.

Chen, C. C., \& Tseng, Y. De. (2011). Quality evaluation of product reviews using an information quality framework. Decision Support Systems, 50(4), 755-768. https://doi.org/10.1016/j.dss.2010.08.023

Kim, N. E., \& Kim, M. H. (2010). The Impacts of Tourism e-WOM information Characteristics and Community Interactivity on e-WOM Information Usefulness and e-WOM Effects.

Bickart, B., \& Schindler, R. M. (2001). Internet Forums As Influential. Journal of Interactive Marketing, 15(3), 31-40.

López, M., \& Sicilia, M. (2014). Determinants of E-WOM influence: The role of consumers' internet experience. Journal of Theoretical and Applied Electronic Commerce Research. https://doi.org/10.4067/S071818762014000100004

Chu, S. C., \& Choi, S. M. (2011). Electronic word-of-mouth in social networking sites: A cross-cultural study of the United States and China. Journal of Global Marketing, 24(3), $263-281$. https://doi.org/10.1080/08911762.2011.592461 
Sallam, M. A. (2016). The Impact of Brand Image and Corporate Branding on Consumer's Choice: The Role of Brand Equity. International Journal of Marketing Studies, 8(1), 98. https://doi.org/10.5539/ijms.v8n1p98

Agmeka, F., Wathoni, R. N., \& Santoso, A. S. (2019). The influence of discount framing towards brand reputation and brand image on purchase intention and actual behaviour in e-commerce. Procedia Computer Science, 161, 851-858. https://doi.org/10.1016/j.procs.2019.11.192

Kapoor, R. (2016). Managing Loyalty through Brand Image, Judgement and Feelings for Leveraging Power Brands. Management \& Marketing. Challenges for the Knowledge Society, 11(4), 624-637. https://doi.org/10.1515/mmcks-2016

MOHAMMAD, A. A. S. (2017). The Impact of Brand Experiences, Brand Equity and Corporate Branding on Brand Loyalty: Evidence from Jordan. International Journal of Academic Research in Accounting, Finance and Management Sciences, 7(3), 58-69. https://doi.org/10.6007/ijarafms/v7-i3/3102

Chaudhuri, A., \& Holbrook, M. B. (2001). The chain of effects from brand trust and brand affect to brand performance: The role of brand loyalty. Journal of Marketing, 65(2), 81-93. https://doi.org/10.1509/jmkg.65.2.81.18255

Maheshwari, V., Lodorfos, G., \& Jacobsen, S. (2014). Determinants of Brand Loyalty: A Study of the Experience-Commitment-Loyalty Constructs. International Journal of Business Administration, 5(6). https://doi.org/10.5430/ijba.v5n6p13

Crespo-Almendros, E., \& Del Barrio-García, S. (2016). Online airline ticket purchasing: Influence of online sales promotion type and Internet experience. Journal of Air Transport Management, 53, $23-34$. https://doi.org/10.1016/j.jairtraman.2016.01.004

Purwitasari, I., Kuswarno, E., Wahyudin, U., \& Damayani, N. A. (2019). Garuda Indonesia new digital experience concept:Airline's challenge in communication marketing in the digital era. International Journal of Recent Technology and Engineering.

Sulaiman, A., Ng, J., \& Mohezar, S. (2008). E-Ticketing as a New Way of Buying Tickets: Malaysian Perceptions. Journal of Social Sciences, 17(2), 149-157. https://doi.org/10.1080/09718923.2008.11892644

Hair, J. F., Anderson, R. E., Tatham, R. ., \& Black, W. C. (2006). Multivariate Data Analysis. Sixth Edition. UK: Prentice-Hall International. 